\title{
The Injury among Elderly in Indonesia: Analysis of the 2018 Indonesian Basic Health Survey
}

\author{
Suci Wulansari ${ }^{1}$, Veranita Prabaningrum ${ }^{1}$, Rukmini Rukmini ${ }^{1}$, Agung Dwi Laksono ${ }^{2}$ \\ ${ }^{1}$ Researcher, Functional Unit of Health Technology Innovation, Ministry of Health, Jakarta. Indonesia, \\ ${ }^{2}$ Researcher, Center of Research and Development of Humanities and Health Management, Ministry of Health,
} Jakarta, Indonesia

\begin{abstract}
The elderly are one of the vulnerable groups. This study was aimed at analyzing descriptive statistics of the incidence of injury in the elderly in Indonesia. The data derived from the 2018 Indonesia Basic Health Survey. The analysis was performed statistically descriptive. The analysis was carried out with a sample of 85,358 elderly.The results show that in all types of characteristics the highest proportion of injuries was lower limb injury, followed by upper limb injury. The incidence of lower limb injury in the 60-69 age group was higher than in any other age group. Meanwhile, upper limb injuries were more common in the 70-79 age group. The incidence of injury in various locations in males was higher than in female elderly, except at the location of head and stomach injuries which have the same proportion. The proportions of abrasions and sprains were most common in the 70-79 age group, male, senior high school, and the middle wealth status. The proportion of blisters/bruises affects the elderly in urban areas, in contrast to sprains which are more common in rural elderly. In all age groups, the most common incidence was abrasions/bruises, followed by sprains, with the largest proportion in the 70-79 age group. The public servant/army/police have the highest proportion of abrasions/bruises than other work types.It was concluded that the highest proportion of injuries were lower limb injuries, followed by upper limb injuries. Meanwhile, the most common types of injuries experienced by the elderly are abrasions/bruises.
\end{abstract}

Keywords: injury, elderly, big data, community health, public health.

\section{Introduction}

WHO states that the elderly are one of the vulnerable groups. Other vulnerable groups are children, pregnant women, people who are malnourished, and people who are sick or have immune disorders ${ }^{1}$. Trends show that the proportion of elderly people is increasing and requires more attention. This condition is a result of the development of better health ${ }^{2,3}$.

Indonesia's population dynamics have also shifted to the elderly population group. This is evidenced by the increasing life expectancy in Indonesia. Life expectancy

\section{Corresponding Author:}

Agung Dwi Laksono

Email: agung.dwi.laksono-2016@fkm.unair.ac.id in 2010 is 69.81 years old. Then that number increased to 70.90 years old (male 69.09 years old, female 72.8 years old) in 2016. Finally, the life expectancy rate of 70.90 years old shows that babies born in 2016 can live to the age of 70 years old ${ }^{4,5}$.

Injury/physical trauma base on the health reflection means any permanent or semi-permanent disturbance of structure or function of any part of the body caused by an external agency. Such agency may be mechanical, thermal, chemical, electrical, or radiational. The term may also be applied to damage caused by infecting organisms or to psychological trauma ${ }^{6}$. Geriatric trauma patients are less likely to be injured than younger people. Moreover, they are more likely to have fatal outcomes ${ }^{7}$.

Falling is one of the problems that often occur in the elderly where it is related to changes in the function 
of disease organs and the environment ${ }^{8-10}$.About $30 \%$ of the elderly have experienced falls within one year. Various types of injuries incurred due to falls can be mild to severe, such as head injuries, soft tissue injuries to fractures. It is estimated that about $1 \%$ of elderly people who fall have a fracture of the femur column, $5 \%$ have fractures of other bones such as ribs, humerus, pelvis, and others. About 5\% have soft tissue injuries and fractures ${ }^{9,10}$.Based on the background description, this study aims to analyze descriptive statistics of the incidence of injury in the elderly in Indonesia.

\section{Materials and Methods}

The data source used in this research was the 2018 Indonesian Basic Health Survey. The 2018 Indonesian Basic Health Survey was a national scale survey conducted by theIndonesian Ministry of Health. The unit of analysis in this study was the elderly ( $\geq 60$ years old). With the multi-stage cluster random sampling method, it was found that as many as 85,358 elderly respondents.

The incident of injury was the proportion of injuries to the elderly population in the last 12 months that resulted in disrupted daily activities ${ }^{11}$. The analysis was carried out by statistical descriptive by observing the distribution by province and demographic characteristics of the elderly. The demographic characteristics of the elderly who were involved were age group, type of place of residence, gender, education level, work type, and wealth status.

\section{Results and Discussion}

Table 1 presents the proportion of injuries in the elderly by demographic characteristics. Characteristics include classification of the elderly according to age group, type of place of residence, gender, education level, occupation type, and wealth status.

Based on demographic characteristics, the largest proportion of injury incidence is experienced by the female elderly, middle elderly, and those who live in urban areas. Meanwhile, based on the education level and occupation type, the elderly with no education or never going to school and not working suffered the most injuries. The proportion of injury incidence was almost even in all status of wealth.

The parts of the body affected by injury are classified according to ICD-10. Respondents can experience more than one part (multiple injuries). The classification of the injured body parts is grouped into the head (including the eyes, nose, ears, mouth, face, and neck), chest (covering the front of the body from the top of the waist to the bottom of the neck including the sternum), back (covering the back of the body from above waist to lower), neck including the spine, stomach (covering the body from below the waist, front and back including the genitals and internal organs), upper limbs (covering the upper arms, forearms, back of the hands, palms, and fingers), lower limbs (including thighs, calves, soles, and toes) $)^{11}$.

Table1. The proportion of injury amongthe elderly by demographic characteristics $(n=85,358)$

\begin{tabular}{|c|c|c|c|}
\hline \multirow{2}{*}{ Demographic Characteristics } & \multicolumn{3}{|c|}{ Injury } \\
\cline { 2 - 4 } & $\mathbf{\%}$ & $\mathbf{9 5 \%}$ CI & N (Adjusted) \\
\hline Age group & & & 23,588 \\
\hline $60-69$ & 8.5 & $8.0-9.0$ & 7,284 \\
\hline $70-79$ & 9.4 & $8.4-10.5$ & 54,486 \\
\hline \hline 80 & 8.2 & $7.9-8.5$ & \\
\hline Type of place of residence & & & 40,892 \\
\hline Urban & 8.5 & $7.2-8.0$ & 45,542 \\
\hline Rural & 7.9 & $8.3-9.1$ & \\
\hline Gender & & & 43,373 \\
\hline
\end{tabular}


Cont... Table1. The proportion of injury amongthe elderly by demographic characteristics $(\mathbf{n}=\mathbf{8 5 , 3 5 8 )}$

\begin{tabular}{|c|c|c|c|}
\hline Female & 8.7 & $8.3-9.1$ & 41,985 \\
\hline \multicolumn{4}{|l|}{ Education level } \\
\hline No education & 8.9 & $8.2-9.5$ & 17,943 \\
\hline Didn't graduate from elementary school & 8.1 & $7.7-8.7$ & 23,763 \\
\hline Elementary school & 8.0 & $7.5-8.5$ & 26,589 \\
\hline Junior high school & 8.0 & $7.2-9.0$ & 6,381 \\
\hline Senior high school & 7.3 & $6.5-8.3$ & 7,342 \\
\hline College & 8.4 & $7.1-9.8$ & 3,340 \\
\hline \multicolumn{4}{|l|}{ Occupation type } \\
\hline Not works & 13.2 & $10.9-16.9$ & 39,021 \\
\hline Public servant/army/police & 7.3 & $5.3-10.0$ & 1,074 \\
\hline Private sector & 6.4 & $4.6-8.7$ & 1,226 \\
\hline Entrepreneur & 7.6 & $6.8-8.5$ & 8,592 \\
\hline Farmer & 7.3 & $6.9-7.8$ & 26,683 \\
\hline Fisherman & 7.4 & $5.0-10.9$ & 492 \\
\hline Labor/Driver/Maid & 8.3 & 7.2-9.6 & 5,139 \\
\hline Others & 8.1 & $7.1-9.2$ & 5,296 \\
\hline \multicolumn{4}{|l|}{ Wealth status } \\
\hline Poorest & $8.1 \%$ & 7.6-8.7 & 19,869 \\
\hline Poorer & $8.4 \%$ & $7.8-9.1$ & 16,814 \\
\hline Middle & $8.4 \%$ & $7.7-9.1$ & 15,586 \\
\hline Richer & $7.5 \%$ & $7.0-8.1$ & 15,733 \\
\hline Richest & $8.4 \%$ & 7.8-9.1 & 17,357 \\
\hline
\end{tabular}

Source: the 2018 Indonesian Basic Health Survey

In all types of characteristics, the highest proportion of injuries was lower limb injury, followed by upper limb injury. The incidence of lower limb injury in the young elderly is higher than in the middle and old elderly. Meanwhile, upper limb injuries were mostly experienced by the middle elderly. The incidence of injury in various locations in males is more than in females except for the head and abdominal injuries which have the same proportion.

Types of injury based on the part of the body that are injured are also divided into abrasions/bruises, wounds/ cuts/stab wounds, sprains, fractures, and severed limbs. Table 3 presents the types of injuries among the elderly in Indonesia.
The proportion of abrasions and sprains most often occurs in the middle elderly, male, secondary education, and poor wealth status. The proportion of abrasions/ bruises is high in urban areas, in contrast to sprains which are more common in rural residents. At all levels of elderly people, the highest incidence is abrasions/ bruises, followed by sprains, where the largest proportion is experienced by the middle elderly. The type of work of public servant/army/police has the highest proportion of experiencing bruises compared to other types of occupation. Injuries suffered by the elderly are also divided into eye injuries, brain injuries, internal organ injuries, burns, and others. 
Table 2. The body part of injury among the elderly in Indonesia $(\mathbf{n}=\mathbf{8 5 , 3 5 8})$

\begin{tabular}{|c|c|c|c|c|c|c|c|c|}
\hline \multirow{2}{*}{\multicolumn{2}{|c|}{ Characteristics }} & \multicolumn{6}{|c|}{ Injured body part (\%) } & \multirow{2}{*}{$\begin{array}{c}\mathrm{N} \\
\text { (Adjusted) }\end{array}$} \\
\hline & & Head & Chest & Back & Abdomen & $\begin{array}{l}\text { Upper } \\
\operatorname{limb}\end{array}$ & $\begin{array}{c}\text { Lower } \\
\operatorname{limb}\end{array}$ & \\
\hline \multicolumn{9}{|c|}{ Age group } \\
\hline . & $60-69$ & 14.0 & 4.3 & 12.1 & 2.3 & 30.1 & 60.2 & 23,588 \\
\hline . & $70-79$ & 15.5 & 3.7 & 13.9 & 3.0 & 31.4 & 57.5 & 7,284 \\
\hline . & $\geq 80$ & 17.8 & 1.7 & 16.4 & 4.0 & 29.2 & 56.9 & 54,486 \\
\hline \multicolumn{9}{|c|}{ Type of place of residence } \\
\hline . & Urban & 16.3 & 3.7 & 11.6 & 2.6 & 29.1 & 60.0 & 40,892 \\
\hline . & Rural & 13.1 & 4.1 & 14.6 & 2.8 & 31.7 & 58.0 & 45,542 \\
\hline \multicolumn{9}{|c|}{ Gender } \\
\hline . & Male & 14.8 & 4.3 & 11.7 & 2.7 & 30.5 & 62.1 & 43,373 \\
\hline . & Female & 14.8 & 3.5 & 14.0 & 2.7 & 30.2 & 56.7 & 41,985 \\
\hline \multicolumn{9}{|c|}{ Education level } \\
\hline . & No education & 13.6 & 2.3 & 13.9 & 2.3 & 32.8 & 58.5 & 17,943 \\
\hline . & $\begin{array}{l}\text { Didn't graduate from } \\
\text { elementary school }\end{array}$ & 15.1 & 4.1 & 13.2 & 3.2 & 30.2 & 57.2 & 23,763 \\
\hline . & Elementary school & 14.0 & 4.7 & 12.8 & 1.9 & 30.1 & 59.4 & 26,589 \\
\hline . & Junior high school & 18.5 & 6.2 & 15.3 & 4.6 & 31.6 & 58.1 & 6,381 \\
\hline . & Senior high school & 18.1 & 2.4 & 10.1 & 2.3 & 24.0 & 64.6 & 7,342 \\
\hline . & College & 13.2 & 3.6 & 10.1 & 4.4 & 29.7 & 64.6 & 3,340 \\
\hline \multicolumn{9}{|c|}{ Occupationtype } \\
\hline . & Not works & 16.9 & 3.6 & 13.4 & 2.7 & 29.5 & 57.4 & 39,021 \\
\hline . & $\begin{array}{l}\text { Public servant/army/ } \\
\text { police }\end{array}$ & 9.5 & 7.7 & 11.2 & 9.7 & 39.1 & 68.8 & 1,074 \\
\hline . & Private sector & 5.6 & 1.8 & 14.5 & & 25.4 & 65.0 & 1,226 \\
\hline . & Entrepreneur & 12.9 & 3.7 & 11.5 & 3.5 & 31.9 & 61.7 & 8,592 \\
\hline . & Farmer & 10.6 & 4.5 & 14.0 & 2.8 & 32.6 & 60.5 & 26,683 \\
\hline . & Fisherman & 6.3 & 0.8 & 3.3 & 9.7 & 26.9 & 68.4 & 492 \\
\hline . & Labor/Driver/Maid & 15.2 & 4.4 & 10.3 & 0.7 & 24.6 & 63.4 & 5,139 \\
\hline . & Others & 23.3 & 2.5 & 10.8 & 1.2 & 30.9 & 54.6 & 5,296 \\
\hline \multicolumn{9}{|c|}{ Wealth status } \\
\hline . & Poorest & 14.4 & 3.6 & 14.9 & 1.9 & 30.3 & 57.6 & 19,869 \\
\hline . & Poorer & 13.6 & 3.3 & 12.7 & 3.2 & 29.2 & 60.2 & 16,814 \\
\hline . & Middle & 14.6 & 4.1 & 13.0 & 2.3 & 33.9 & 57.3 & 15,586 \\
\hline . & Richer & 13.4 & 4.6 & 13.5 & 2.9 & 30.8 & 58.6 & 15,733 \\
\hline . & Richest & 17.8 & 3.8 & 10.9 & 3.2 & 28.1 & 61.6 & 17,357 \\
\hline
\end{tabular}

Source: the 2018 Indonesian Basic Health Survey 
The incidence of trauma in elderly patients increases due to physical and psychological changes due to the processes that occur during increasing age. This is a major trigger for increased dependence as well as morbidity and mortality in the elderly ${ }^{12,13}$.

Table 3. Type of injury among the elderly in Indonesia $(n=85,358)$

\begin{tabular}{|c|c|c|c|c|c|c|}
\hline \multirow[b]{2}{*}{ Characteristics } & \multicolumn{5}{|c|}{ Type of Injury (\%) } & \multirow[b]{2}{*}{ N (Adjusted) } \\
\hline & $\begin{array}{c}\text { Blisters / } \\
\text { bruises }\end{array}$ & $\begin{array}{c}\text { Cut/ } \\
\text { stab } \\
\text { wound }\end{array}$ & Sprains & Fracture & $\begin{array}{l}\text { Severed } \\
\text { limbs }\end{array}$ & \\
\hline \multicolumn{7}{|l|}{ Age group } \\
\hline $60-69$ & 53.5 & 19.8 & 37.0 & 9.3 & 0.7 & 23,588 \\
\hline $70-79$ & 54.6 & 14.2 & 39.5 & 11.1 & 0.3 & 7,284 \\
\hline$\geq 80$ & 51.6 & 12.8 & 38.9 & 15.6 & 0.2 & 54,486 \\
\hline \multicolumn{7}{|l|}{ Type of place of residence } \\
\hline Urban & 55.1 & 16.5 & 36.8 & 11.4 & 0.6 & 40,892 \\
\hline Rural & 52.0 & 18.6 & 39.2 & 9.4 & 0.5 & 45,542 \\
\hline \multicolumn{7}{|l|}{ Gender } \\
\hline Male & 56.2 & 24.7 & 32.0 & 9.6 & 0.6 & 43,373 \\
\hline Female & 51.7 & 11.9 & 42.5 & 11.1 & 0.5 & 41,985 \\
\hline \multicolumn{7}{|l|}{ Education level } \\
\hline No education & 50.8 & 13.8 & 39.8 & 12.3 & 0.1 & 17,943 \\
\hline $\begin{array}{l}\text { Didn't graduate from } \\
\text { elementary school }\end{array}$ & 55.9 & 18.6 & 39.2 & 8.1 & 0.9 & 23,763 \\
\hline Elementary school & 52.3 & 18.0 & 36.7 & 10.2 & 0.6 & 26,589 \\
\hline Junior high school & 52.0 & 21.8 & 34.7 & 13.3 & 0.5 & 6,381 \\
\hline Senior high school & 59.2 & 19.2 & 34.6 & 11.2 & 0.5 & 7,342 \\
\hline College & 56.7 & 15.9 & 39.8 & 11.3 & 0.0 & 3,340 \\
\hline \multicolumn{7}{|l|}{ Occupation type } \\
\hline Not works & 53.9 & 11.5 & 39.9 & 12.1 & 0.6 & 39,021 \\
\hline $\begin{array}{l}\text { Public servant/army/ } \\
\text { police }\end{array}$ & 67.7 & 27.2 & 21.3 & 12.5 & 3.3 & 1,074 \\
\hline Private sector & 49.0 & 24.6 & 29.1 & 5.5 & & 1,226 \\
\hline Entrepreneur & 57.4 & 17.8 & 37.3 & 11.0 & 0.3 & 8,592 \\
\hline Farmer & 50.1 & 24.7 & 38.9 & 7.1 & 0.4 & 26,683 \\
\hline Fisherman & 40.7 & 29.0 & 27.3 & 13.1 & 8.1 & 492 \\
\hline Labor/Driver/Maid & 58.7 & 26.8 & 29.4 & 10.5 & & 5,139 \\
\hline Others & 56.1 & 20.8 & 31.1 & 11.9 & 0.1 & 5,296 \\
\hline \multicolumn{7}{|l|}{ Wealth status } \\
\hline Poorest & 56.5 & 15.7 & 39.0 & 9.8 & 1.0 & 19,869 \\
\hline Poorer & 54.7 & 18.1 & 39.0 & 8.6 & 0.6 & 16,814 \\
\hline Middle & 49.3 & 20.0 & 38.4 & 12.3 & 0.3 & 15,586 \\
\hline Richer & 52.0 & 16.2 & 37.2 & 10.0 & 0.2 & 15,733 \\
\hline Richest & 54.5 & 17.7 & 35.9 & 11.6 & 0.5 & 17,357 \\
\hline
\end{tabular}

Source: the 2018 Indonesian Basic Health Survey 
In all countries including developing countries such as Indonesia, the growth in the number of elderly people increases rapidly with the increase in life expectancy due to economic and social improvements ${ }^{14,15}$. Although traumatic injuries are more common in children and young adults, the morbidity and mortality rates due to injury are higher in the elderly than in young adults ${ }^{11}$. Previous studies in the United States suggested that the proportion of injuries to the elderly population was $14 \%$, with the main cause being falls ${ }^{16}$.

Efforts to create a friendly environment for geriatrics need to be done by the central and local governments by compiling various regulations to reduce the risk of injury. The Ministry of Health through the Minister of Health Regulation Number 67 of 2015 has stipulated the implementation of elderly health services at public health center. However, the daily environment in which elderly individuals live and do activities is not entirely regulated by regulations ${ }^{17}$.

\section{Conclusions}

Based on the results of the study, the highest proportion of injuries was lower limb injuries, followed by upper limb injuries. Meanwhile, the most common types of injuries experienced by the elderly were abrasions/bruises.

Acknowledgments: The author would like to thank the National Institute of Research and Development, the $\mathrm{MOH}$ of the Republic of Indonesia, who has agreed to allow the Riskesdas 2018 data to be analyzed in this article.

\section{Source of Funding: Self-funding}

Ethical Clearance: The research had an ethical clearance that was approved by the national ethical committee (ethic number: LB.02.01/2/KE.378/2019). Informed consent was used during data collection, which considered aspects of the data collection procedure, voluntary, and confidentiality.

Conflict of Interest: The authors declare no conflict of interest, financial or otherwise.

\section{References}

1. World Health Organization. Vulnerable groups [Internet]. 2018 [cited 2018 Jul 10]. Available from: http://www.who.int/environmental_health_ emergencies/vulnerable_groups/en/

2. Wulandari RD, Qomarrudin MB, Supriyanto S, Laksono AD. Socioeconomic Disparities in Hospital Utilization among Elderly People in Indonesia. Indian J Public Heal Res Dev. 2019;10(11):18004.

3. Laksono AD, Nantabah ZK, Wulandari RD. Access Barriers to Health Center for Elderly in Indonesia. Bull Heal Syst Res. 2018;21(4):228-35.

4. Badan Pusat Statistik. Indikator Strategis Nasional [Internet]. 2018 [cited 2018 Jul 10]. Available from: https://www.bps.go.id/QuickMap?id=0000000000

5. Wulandari RD, Laksono AD. Urban-Rural Disparity: The Utilization of Primary Health Care Center Among Elderly in East Java, Indonesia. J Adm Kesehat Indones [Internet]. 2019;7(2):14754. Available from: https://e-journal.unair.ac.id/ JAKI/article/view/11267

6. Youngson RM. Collins Dictionary of Medicine. Fourth. Collins; 2005.

7. Arslan B. Geriatric Trauma [Internet]. London: IntechOpen; 2018. Available from: https://www. intechopen.com/books/trauma-surgery/geriatrictrauma

8. Setiati S. Balance disorders, falls and fractures. In: Sudoyo AW, Setiyohadi B, Alwi I, Simadibrata M SS, editor. Internal medicine textbook. Fourth Edi. Jakarta: Interna Publishing; 2006.

9. Andayani R. Fall down. In: RB D, editor. Geriatric Textbook. Third Edit. Jakarta; 2006.

10. Ariawan I, Kuswardhani R, Astika I, Aryana I. The relationship between activities specific balance confidence scale with age and falls in the elderly in the geriatric polyclinic of Sanglah Hospital, Denpasar. J Penyakit Dalam. 2011;12(1):33-7.

11. National Institute of Health Research and Development of The Indonesia Ministry of Health. The 2018 Indonesia Basic Health Survey (Riskesdas): National Report [Internet]. Jakarta; 2019. Available from: http://labmandat. 
litbang.depkes.go.id/images/download/ laporan/ RKD/2018/ Laporan \%7B\%5C_\%7 DNasional\%7B\%5C_ \%7 DRKD2018\% 7B\%5C_ $\% 7$ DFINAL.pdf

12. Tejiram S, Cartwright J, Taylor SL, Hatcher VH, Galet C, Skeete DA, et al. A Prospective Comparison of Frailty Scores and Fall Prediction in Acutely Injured Older Adults. J Surg Res. 2021;257:326-32.

13. Kanters TA, van de Ree CLP, de Jongh MAC., Gosens T, Hakkaart-van Roijen L. Burden of illness of hip fractures in elderly Dutch patients. Arch Osteoporos. 2020;15(1):Article number 11.

14. Jia H, Lubetkin EI. Life expectancy and active life expectancy by marital status among older U.S. adults: Results from the U.S. Medicare Health Outcome Survey (HOS). SSM - Popul Heal. 2020;12:Article number 100642.
15. Miladinov G. Socioeconomic development and life expectancy relationship: evidence from the EU accession candidate countries. Genus. 2020;76(1):Article number 2.

16. Abraham MK, Cimino-Fiallos N. Falls in the Elderly: Causes, Injuries, and Management [Internet]. Medscape. 2019 [cited 2020 Sep 21]. Available from: https://reference.medscape.com/ slideshow/falls-in-the-elderly-6012395

17. Indonesian Ministry of Health. Regulation of the Minister of Health Number 67 of 2015 concerning Implementation of Elderly Health Services at Community Health Centers (Peraturan Menteri Kesehatan Nomor 67 Tahun 2015 tentang Penyelenggaraan Pelayanan Kesehatan Lanjut Usia di Pusat Keseh. Regulation of the Minister of Health Number 67 of 2015 Indonesia; 2015 p. $1-20$. 